Article

\title{
Geopolymer-Bonded Laminated Veneer Lumber as Environmentally Friendly and Formaldehyde-Free Product: Effect of Various Additives on Geopolymer Binder Features
}

\author{
Ali Shalbafan $1, *\left(\mathbb{D}\right.$ and Heiko Thoemen ${ }^{2}$ \\ 1 Faculty of Natural Resources and Marine Sciences, Department of Wood and Paper Science and Technology, \\ Tarbiat Modares University, P.O. Box 46414-356, Noor, Iran \\ 2 Architecture, Wood and Civil Engineering, Bern University of Applied Sciences, CH-2500 Biel 6, Switzerland; \\ heiko.thoemen@bfh.ch \\ * Correspondence: ali.shalbafan@modares.ac.ir; Tel.: +98-912-253-8764
}

Received: 7 November 2019; Accepted: 30 December 2019; Published: 14 January 2020

\begin{abstract}
Environmentally friendly and formaldehyde-free laminated veneer lumber (LVL) was manufactured using geopolymer constituents as binder. The main aim of the study was to improve the bonding quality between the geopolymer binder and the wood constituents. To this end, the effect of various additives (phenol flakes, conventional silica fume, and grafted silica fume with 3-aminopropyltriethoxysilane (APTES)) in the geopolymer binder features were explored via gel time and viscosity measurements, differential scanning calorimetry (DSC), and Fourier transom infrared spectroscopy. The mechanical properties (shear, bending, and compression) of LVL panels were also determined. Results showed that adding both types of silica fume had a positive impact on the geopolymer binder features. The formation of an alkaline aluminosilicate network was proven by observing the characteristics peaks of geopolymer binder at about 683 and $970 \mathrm{~cm}^{-1}$. A peak temperature of about $98{ }^{\circ} \mathrm{C}$ was determined for the geopolymer binder curing via DSC analysis. The mechanical properties were the highest for LVL panels made of geopolymer binder with grafted silica fume. It is feasible that the APTES used as grafting agent created a better bonding mechanism with superficial wood cells. In summary, the produced LVL panel showed good properties, but it still needs to be further improved to reach the required levels for use in interior and humid application.
\end{abstract}

Keywords: geopolymer; mineral binder; additives; laminated veneer lumber; shear strength; APTES

\section{Introduction}

Laminated veneer lumber (LVL), one of the most important engineered wood products (EWPs), offers all the superior advantages of the parent wood as well as improved properties due to its laminated structure. LVL is manufactured by bonding together rotary peeled or sliced thin wood veneers under heat and pressure. Prior to lamination, the veneers are glued, and the grain of each veneer is oriented in the same direction. This makes LVL stronger, straighter, and more uniform than the parent wood and overcomes some of wood's natural drawbacks such as strength-reducing knots [1]. LVL can be used for exterior and interior applications including beams, lintels, purlins, truss chords, stairs, and furniture applications [2]. The manufacture of LVL currently almost fully depends on the use of synthetic adhesives, mainly based on formaldehyde (e.g., urea formaldehyde (UF) and phenol formaldehyde (PF)) as a binder due to its low cost and sufficient properties. Formaldehyde-based adhesives have dominated the application over the last 80 years and are still dominating the field of wood products bonding [3]. 
LVL produced using formaldehyde-based adhesive causes a serious challenge for further development and application of products made of LVL [4]. The formaldehyde can irritate the eyes, as well as the respiratory and nervous systems, and possibly lead to cancer and leukemia $[5,6]$. Hence, the allowed level of formaldehyde emission from wood products has been limited by the announcement of the International Agency for Research on Cancer and Environmental Protection Agencies in various countries, forcing companies to reduce formaldehyde emission in their products. In addition, LVL may not be sufficiently resistant to fire and decay to be used for exterior applications, unless treatment or protection is provided. A lot of effort has already been made toward minimizing the aforementioned issues $[3,7,8]$. However, most of these approaches could result in an obvious increase in cost and complexity of the preparation process. In this context, mineral binders have shown great potential in replacing the conventional synthetic binders for the production of EWPs [9-11]. The use of a mineral binder as an adhesive for the bonding of veneer, apart from the fact that the mineral components are formaldehyde-free, has several other advantages compared to using synthetic adhesives. Mineral binders are resistant to fire, extreme temperature, acids, mildew, and fungi [10-12].

Geopolymer $\left(\mathrm{M}_{n}\left\{-\left(\mathrm{Si}-\mathrm{O}_{2}\right)_{z}-\mathrm{Al}-\mathrm{O}-\right\}_{n} \cdot w \mathrm{H}_{2} \mathrm{O}, \mathrm{M}=\mathrm{Na}\right.$, or $\left.\mathrm{K}\right)$ is an emerging class of binding materials made by pozzolanic powder activated by an alkaline solution [13,14]. Pozzolans are defined as materials containing high amounts of silicon dioxide $\left(\mathrm{SiO}_{2}\right)$ and aluminum oxide $\left(\mathrm{Al}_{2} \mathrm{O}_{3}\right)$ that are either raw or calcined natural materials $[15,16]$. A three-dimensional amorphous aluminosilicate network is formed due to the geopolymerization process through the linking of $\mathrm{SiO}_{4}$ and $\mathrm{AlO}_{4}$ by sharing their oxygen atoms in a high alkalinity environment $[17,18]$. Although numerous studies have been dedicated to the reinforcement of the geopolymer matrix with wood $[10,19,20]$, only a few studied the potential of geopolymer as a binder for solid wood bonding [21-23]. A few studies have also been devoted to the use of geopolymer as a binder to produce wood-based products [9,24-26]. No literature is available on the use of geopolymer binder to manufacture engineered wood products such as LVL.

Adequate adhesion between two materials (similar or dissimilar) is of great importance for determining the final application of resultant products. The requisite adhesion strength between the materials stems from the intrinsic adhesion forces across the interface of materials, as well as the toughness of adhesive joints [6,27]. Although extensive research has been conducted on bonding improvements of wood with synthetic binders, there are only few studies on wood and inorganic binders [20,28]. Even less information exists about bonding enhancement of geopolymer with wood $[9,29]$. Hence, the main aim of this study was to improve the bonding strength developed between geopolymer binder and wood constituents. To this end, various additives (phenol flakes, conventional silica fume, and grafted silica fume with 3-aminopropyltriethoxysilane (APTES)) were added into the geopolymer binder formulation prior to application for LVL manufacturing. The applicability of these additives to improve the geopolymer features were previously proven by various research studies [30-32]. This work presents the first effort to develop and evaluate the LVL panels based on beech veneer (as an under-utilized wood species in Europe) and geopolymer binder.

An alternative way of enhancing the bonding shear strength of geopolymer binder is the modification of hot-pressing conditions, having the obvious advantages of low cost and easy processing. Hence, prior to LVL production, the curing characteristics of geopolymer binder under various hot-pressing conditions (temperature and time) were also evaluated by the Automated Bonding Evaluation System (ABES) developed by Adhesive Evaluation Systems (Corvallis, OR, USA).

\section{Materials and Methods}

\subsection{Materials}

Beech (Fagus sylvatica) veneers without dead-knots, spiral grain, and with a regular veneer surface with uniform color and structure was purchased from the Hess \& Co. AG in Döttingen, Switzerland. Veneers with dimensions of $500 \times 500 \times 2.7 \mathrm{~mm}^{3}$ and a moisture content of $8.9 \%$ were used for the LVL production. 
Geopolymer binder results from the activation of aluminosilicate powder with the alkaline activator/solution. In this study, the alkaline activator was prepared by admixture of sodium silicate $\left(\mathrm{Na}_{2}\left(\mathrm{SiO}_{2}\right)_{\mathrm{n}} \mathrm{O}\right)$ with potassium hydroxide $(\mathrm{KOH})$. Sodium silicate with a molar ratio of $2.6\left(\mathrm{SiO}_{2} / \mathrm{Na}_{2} \mathrm{O}\right)$ was supplied from Woellner $\mathrm{GmbH}$ (Ludwigshafen, Germany). Commercial potassium hydroxide was supplied from BASF (Ludwigshafen, Germany). Metakaolin as aluminosilicate was supplied from Ferropem (Chambery, France). Various additives to improve the geopolymer binder characteristics were phenol, silica fume, and grafted silica fume. Phenol flakes were supplied from Merck (Darmstadt, Germany). Silica fume (or micro-silica) and grafted silica fume were supplied from Elkem (Kristiansand, Norway). The functionalization agent for the grafting of silica fume was 3-aminopropyltriethoxysilane (APTES) supplied from Sigma-Aldrich. According to the supplier, the amount of APTES for grafting was $5 \%$, on the basis of the mass of the silica fume.

\subsection{Preparation of Geopolymer Binder}

Geopolymer binder in this research was prepared according to the previous studies of Shalbafan [26,29]. After dissolving potassium hydroxide in water, the appropriate amount of sodium silicate (water glass) was added into the solution. The alkaline activator was sealed and stored for a minimum of $24 \mathrm{~h}$ prior to use in order to obtain clear solutions. Then, metakaolin powder and the appropriate content of additives (phenol flakes, silica fume, and grafted silica fume) were gradually added to the prepared alkaline solution and blended with a mixer (1500 rpm). Blending was continued until a homogenous mixture of ingredients was achieved. It must be mentioned that the ratio of alkaline solution to aluminosilicate powder, as well as the mass ratio of water glass to the chemical base, were kept constant in all binder variations at 1 and 1.33, respectively. The content of additives (phenol flakes, micro and grafted silica) added into the geopolymer binder recipe were based on the reference weight of metakaolin powder.

The final solid content of the geopolymer binder without additives was set at $70 \%$. The increase of binder solid content was only up to $1.33 \%$, due to the addition of various additives in the binder recipe. Detailed description of variable compositions of the geopolymer binder is shown in Table 1.

Table 1. Variable composition of geopolymer binder.

\begin{tabular}{ccc}
\hline Sample Code & Types of Additives & Content of Additives (wt \%) $\mathbf{1}^{\mathbf{1}}$ \\
\hline $\mathbf{N}$ & Geopolymer with no additives & - \\
$\mathbf{P}$ & Phenol flakes & $1,3,5,10$ \\
CF & Conventional silica fume & $1,3,5,10$ \\
GF & Grafted silica fume with 3-aminopropyltriethoxysilane (APTES) & $1,3,5,10$ \\
\hline
\end{tabular}

${ }^{1}$ Additives were added on the basis of the reference weight of metakaolin used for binder preparation.

\subsection{Experimental Design}

The curing characteristics of the geopolymer binder under various hot-pressing conditions (temperature and time) were evaluated by means of ABES instrument (Adhesive Evaluation Systems, Corvallis, OR, USA) using beech veneer strips with a nominal dimension of $117 \times 20 \times 0.6 \mathrm{~mm}^{3}$. The wood strips were glued together on the basis of the conventional configuration ( $5 \mathrm{~mm}$ overlap), resulting in an overlapping area of $100 \mathrm{~mm}^{2}$. The adhesive amounts were kept constant at $15 \mu \mathrm{L}$ in all tests. Then, the adherent strips were pressed together at $1.2 \mathrm{~N} / \mathrm{mm}^{2}$ with various pressing temperatures (from 80 to $160^{\circ} \mathrm{C}$ ) and times (from 30 to $360 \mathrm{~s}$ ). The cured overlapped area was cooled down with compressed air for $30 \mathrm{~s}$, prior to shear testing.

\subsubsection{Part 1: Effect of Hot-Pressing Conditions}

In this part, according to a central composite design (CCD), a response surface methodology (RSM) was performed to investigate the effect of hot-pressing temperature (in the range of $80-160^{\circ} \mathrm{C}$ ) and time (in the range of 30-360 s) on the bonding shear strength of the geopolymer binder as the response 
variable. The experimental design and the experimental data are shown in Table 2. The replicates of both factorial and axial (star) points were selected to be three in total. The number of the center point was 5. The data were analyzed using the software Design-Expert. V12.0.3 (Stat-Ease, Inc., Minneapolis, MN, USA). The optimum levels of hot-pressing temperature and time were selected, according to the bonding shear strength, for further evaluation of various additives on the geopolymer binder characteristics.

Table 2. Experimental design and data of the response surface methodology (RSM) design.

\begin{tabular}{|c|c|c|c|c|}
\hline \multirow{2}{*}{$\begin{array}{c}\text { Experiment } \\
\text { No. }\end{array}$} & \multicolumn{2}{|c|}{ Independent Variables } & \multicolumn{2}{|c|}{ Dependent Variables ** } \\
\hline & $\mathrm{A} 1\left({ }^{\circ} \mathrm{C}\right)$ & A2 (s) & SSM (MPa) & SSP (MPa) \\
\hline 1 & 100 & 112.5 & $\begin{array}{l}1.58 \\
1.46 \\
1.57 \\
\end{array}$ & 1.61 \\
\hline 2 & 140 & 112.5 & $\begin{array}{l}3.40 \\
3.60 \\
3.69\end{array}$ & 3.43 \\
\hline 3 & 100 & 277.5 & $\begin{array}{l}2.64 \\
2.96 \\
2.68\end{array}$ & 2.85 \\
\hline 4 & 140 & 277.5 & $\begin{array}{l}3.62 \\
3.84 \\
3.96\end{array}$ & 3.68 \\
\hline 5 & 80 & 195 & $\begin{array}{l}1.37 \\
1.22 \\
1.23\end{array}$ & 1.15 \\
\hline 6 & 160 & 195 & $\begin{array}{l}3.50 \\
3.90 \\
3.77\end{array}$ & 3.82 \\
\hline 7 & 120 & 30 & $\begin{array}{l}2.04 \\
2.23 \\
1.92\end{array}$ & 2.07 \\
\hline 8 & 120 & 360 & $\begin{array}{l}3.62 \\
3.48 \\
3.61\end{array}$ & 3.55 \\
\hline 9 & 120 & 195 & $\begin{array}{l}3.13 \\
3.06 \\
3.37 \\
2.94 \\
3.20\end{array}$ & 3.14 \\
\hline $10 *$ & 140 & 112.5 & $\begin{array}{l}3.66 \\
3.52 \\
3.34\end{array}$ & 3.44 \\
\hline
\end{tabular}

* Experiment No. 10 was the optimized hot-pressing condition determined using the regression model. ${ }^{*}$ SSM represents the shear strength measured in the experiments; SSP represents the shear strength predicted by the regression model.

\subsubsection{Part 1: Effect of Additives Content}

In this part, the geopolymer binders were made from the $0 \mathrm{wt} \%, 1 \mathrm{wt} \%, 3 \mathrm{wt} \%, 5 \mathrm{wt} \%$, and $10 \mathrm{wt} \%$ additives based on metakaolin mass. The prepared binders were characterized by ABES using the optimum hot-pressing conditions determined in the RSM study. Finally, the optimum levels of additives for producing LVL panels were determined, according to the bonding shear strength of geopolymer binder. 


\subsection{Geopolymer Binder Characterization}

The reactivity of the geopolymer binder was analyzed with gel time measurement using a laboratory Gelnorm device with three channels from Gel Instrumente AG (Oberuzwil, Switzerland). The elapsed time until the point when no further stirring was possible was determined as the gel time for a corresponding adhesive composition. An average of three replications was reported for each binder formulation.

A rotational viscometer (Brookfield Viscometer DV2T extra, Middleboro, MA, USA) was used to measure the dynamic viscosity $\left(\right.$ at $20^{\circ} \mathrm{C}$ ) of the geopolymer binder having various additives. The spindle speed of the viscometer was set to $15 \pm 5 \mathrm{rpm}$ to reach a torque of about $70 \pm 10 \%$, depending on the type and content of additives.

The effect of different additives on the cured geopolymer network was characterized by attenuated total reflection Fourier transform infrared spectroscopy (ATR-FTIR). To this end, the geopolymer binder with various additives was fully milled. The spectrogram of those samples was obtained using a Perkin Elmer spectrometer (Waltham, MA, USA). The spectra were recorded in the range of $4000-550 \mathrm{~cm}^{-1}$ using 175 scans at $4 \mathrm{~cm}^{-1}$ resolution.

Differential scanning calorimetry (DSC) was performed on binder composition to evaluate their curing behavior. To this end, DSC 6000 from Perkin Elmer (Waltham, MA, USA) was used with high pressure cells. The geopolymer binder solution of about $20 \mathrm{mg}$, including various additives (based on the metakaolin mass), was weighed in the high-pressure cell prior to scanning. All experiments were conducted under a heating rate of $10^{\circ} \mathrm{C}$. The testing temperature range was $30-250{ }^{\circ} \mathrm{C}$. The onset temperature, peak temperature, and heat of reaction were recorded. Heat of reaction was obtained by integrating the exothermic peak area and was reported as joules per gram $(\mathrm{J} / \mathrm{g})$ of binder solid content.

\subsection{Manufacturing of LVL Panels}

Laminated veneer lumber (LVL) using geopolymer as binder was made of five rotary-peeled beech veneer sheets under laboratory conditions. The binder was spread manually on ply faces using a brush. After binder application, five veneer sheets were parallelly oriented, layer by layer, forming the LVL panels. The ply stacks were then pressed in a laboratory single opening hot press (Höfer Presstechnik GmbH, Taiskirchen, Austria). For all LVL panels, the same hot-pressing schedule was applied. The applied pressure, temperature, and time of the press were $2 \mathrm{MPa}, 140{ }^{\circ} \mathrm{C}$, and $16 \mathrm{~min}$, respectively. The panel thickness was also kept constant at $12 \mathrm{~mm}$ for all LVL panels made by geopolymer binders. The spread amount of the geopolymer binder was equal to $420 \mathrm{~g} / \mathrm{m}^{2}$ on each glue line $\left(500 \times 500 \mathrm{~mm}^{2}\right)$. Three LVL panels were manufactured for each of the variables according to Table 1, resulting in a total of 21 panels. Prior to any process step, both veneer sheets and produced LVL panels were conditioned at $65 \% \pm 3 \%$ relative humidity and $20 \pm 2{ }^{\circ} \mathrm{C}$ temperature for 2 weeks.

\subsection{Characterization of LVL Panels}

The mechanical properties of LVL panels containing the various binder compositions were investigated according to the standard EN 14279 [33]. Under EN 14279, the bending properties (bending strength (MOR) and modulus of elasticity (MOE)) are determined according to EN 310 [34] in both major and minor axis (face and edge bending). Bending tests were performed using a Zwick universal testing machine (Zwick Roell Group, Ulm, Germany) with a constant cross-head displacement rate of $8 \mathrm{~mm} / \mathrm{min}$. The dimensions of bending samples were $290 \times 50 \times 12 \mathrm{~mm}^{3}$ (length $\times$ width $\times$ thickness). Nine samples were prepared for each of the LVL samples.

Under EN 14279 [33], the shear strength of the LVL specimen $\left(130 \times 25 \mathrm{~mm}^{2}\right)$ are recommended to be measured according to EN 314 in connection with Annex A [35,36] for the bonding class 1 (interior conditions) and class 2 (humid conditions). For interior conditions, the samples were soaked in distilled water $\left(20 \pm 2{ }^{\circ} \mathrm{C}\right)$ pretreatment for $24 \mathrm{~h}$. For humid conditions, the samples were first soaked in boiled water for $6 \mathrm{~h}$, removed from the water, and then immersed in water with a temperature 
of $20 \pm 2{ }^{\circ} \mathrm{C}$ for at least $1 \mathrm{~h}$ prior to shear strength measurement. In addition, the samples with no pre-treatment (reference samples) were also tested for comparison. Shear tests were conducted using a Zwick universal testing machine (Zwick Roell Group, Ulm, Germany) with a constant cross-head displacement rate of $0.8 \mathrm{~mm} / \mathrm{min}$. The reported mean of the shear strength value represented the average of 15 samples for each LVL panel.

The axial compression strength parallel to fiber direction of the LVL specimens were performed following the provision in EN 408 [37]. The tests were conducted with a constant rate of cross-head motion of $0.3 \mathrm{~mm} / \mathrm{min}$ in a computer-controlled mechanical test machine (Zwick Roell Group, Ulm, Germany). The modulus of elasticity was not measured. The dimensions of the compression samples were $72 \times 12 \times 12 \mathrm{~mm}^{3}$ (length $\times$ width $\times$ thickness). Figure 1 shows the structure of the samples prepared for mechanical tests.

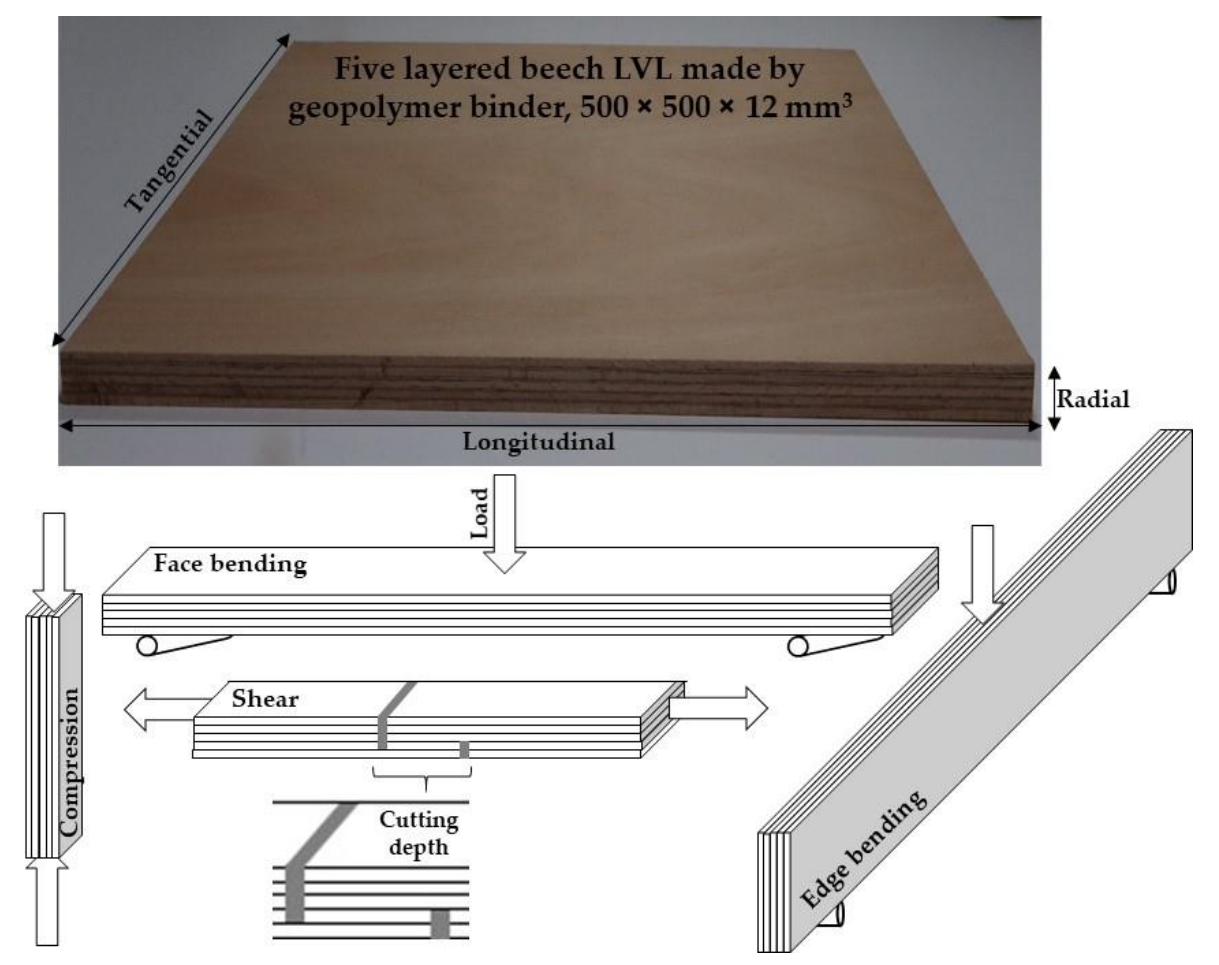

Figure 1. Structure of the produced laminated veneer lumber (LVL) panels and testing specimens.

A one-way analysis of variance (ANOVA) of the LVL properties was performed with the SPSS software (IBM, USA). Statistical differences between variations were evaluated by multiple comparisons on the basis of Duncan test. The statistical significance was set at $p<0.05$.

\section{Results and Discussion}

\subsection{Effect of Processing Parameters on Binder Performance}

The data from experiments no. 1 to 9 (Table 2) were used to develop a regression model (Table 3) for predicting the shear strength of the geopolymer binder. Referring to Table 3, the model had a coefficient of variation below $10 \%$, a coefficient of determination $\left(R^{2}\right)$ and adjusted $R^{2}$ over $96 \%$, and an adequate precision over 4 . Hence, the model is acceptable according to available reports on the RSM study [32]. The optimum levels of pressing temperature and time for evaluating the effect of additives content on geopolymer performance, as well as the LVL production, were determined and validated, which were $140^{\circ} \mathrm{C}$ and $112.5 \mathrm{~s}$, respectively. 
Table 3. A regression model developed on the basis of the experimental data of bonding shear strength of the geopolymer binder.

\begin{tabular}{|c|c|c|c|c|}
\hline Model $^{1}$ & $\begin{array}{c}\text { Coefficients of } \\
\text { Variation (\%) }\end{array}$ & $\begin{array}{c}\text { Coefficient of } \\
\text { Determination }\left(R^{2}\right)\end{array}$ & Adjusted $R^{2}$ & Adequate Precison \\
\hline $\begin{array}{c}\mathrm{Y}=-11.49+0.16 \mathrm{X}_{1}+ \\
0.027 \mathrm{X}_{2}-0.00015 \mathrm{X}_{1} \mathrm{X}_{2}- \\
0.00040 \mathrm{X}_{1}^{2}-0.000012 \mathrm{X}_{2}^{2}\end{array}$ & 6.15 & 0.970 & 0.967 & 35.52 \\
\hline
\end{tabular}

The effect of hot-pressing temperature and time on the bonding shear strength of the geopolymer binder was simulated by using the regression model, as shown in Figure 2. As shown in Figure 2, the hot-pressing temperature and time were significantly influenced by the bonding shear strength of the geopolymer binder. At a lower press time than $112.5 \mathrm{~s}$, the bonding shear strength of the geopolymer binder was increased by elevating the press temperature to $160{ }^{\circ} \mathrm{C}$. At a lower press temperature than $140^{\circ} \mathrm{C}$, the bonding shear strength of the geopolymer binder was also increased by extending the press time to $360 \mathrm{~s}$. According to Bing-hui et al. [14], elevating curing temperature will accelerate the dissolution, polymerization, and re-precipitation processes of the geopolymerization reaction. Hence, it can be noted that a high press temperature and time, in these ranges, intensifies the geopolymerization process through a higher dissolution of binder ingredients, and accordingly, the appropriate completion of geopolymer network formation [26,38]. Conversely, the bonding shear strength tended to stay constant when both the press temperature and time are increased beyond $140{ }^{\circ} \mathrm{C}$ and $112.5 \mathrm{~s}$, respectively. The reason might be that the dissolution and polycondensation processes may not have developed completely whereas some free water in the binder slurry evaporated due to the fast heat development [14].

(A)

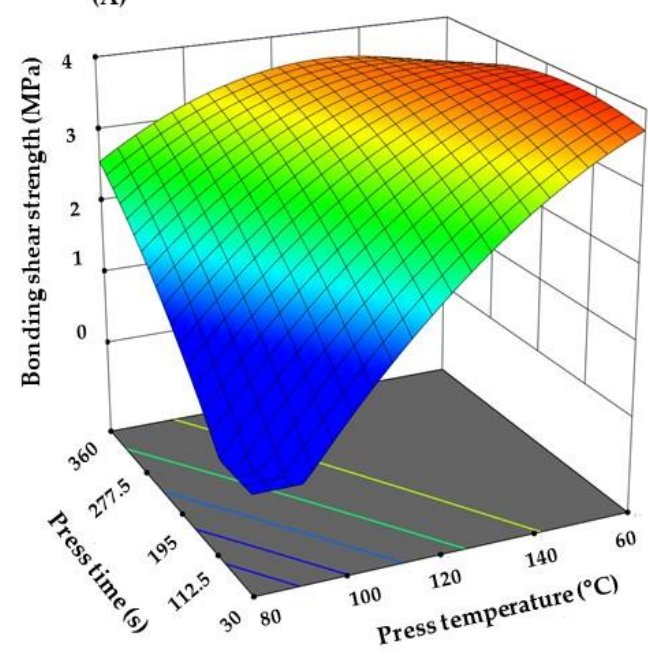

(B)

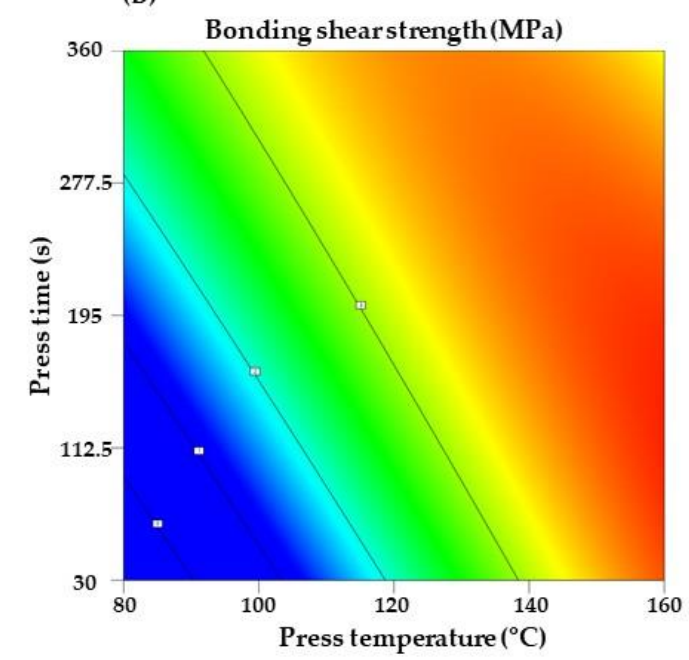

Figure 2. The interactive effect of hot-pressing temperature and time on the bonding shear strength of geopolymer binder determined by RSM simulation using the regression model, (A) three-dimensional picture and (B) two-dimensional picture.

The optimum levels of pressing temperature $\left(140^{\circ} \mathrm{C}\right)$ and time $(112.5 \mathrm{~s})$ obtained by RSM modelling was used to evaluate the effect of additives content on the bonding shear strength of geopolymer binder using the ABES instrument (Figure 3). As shown in Figure 3, the additives content had obvious effects on the bonding shear strength. The shear strength of geopolymer binder with no additives was about 3.5 MPa. Adding various amounts of phenol flakes into the geopolymer binder formulation showed no significant influence on the bonding shear strength. The bonding shear strength of the reference binder was increased about $45 \%$ after the addition of $10 \%$ conventional silica fume, reaching 
a value of about 5.1 MPa. The higher the added silica fume, the higher the bonding shear strength in the geopolymer binder. The addition of silica fume to the binder formulation involved the modification of the geopolymer chemistry $[15,31]$.

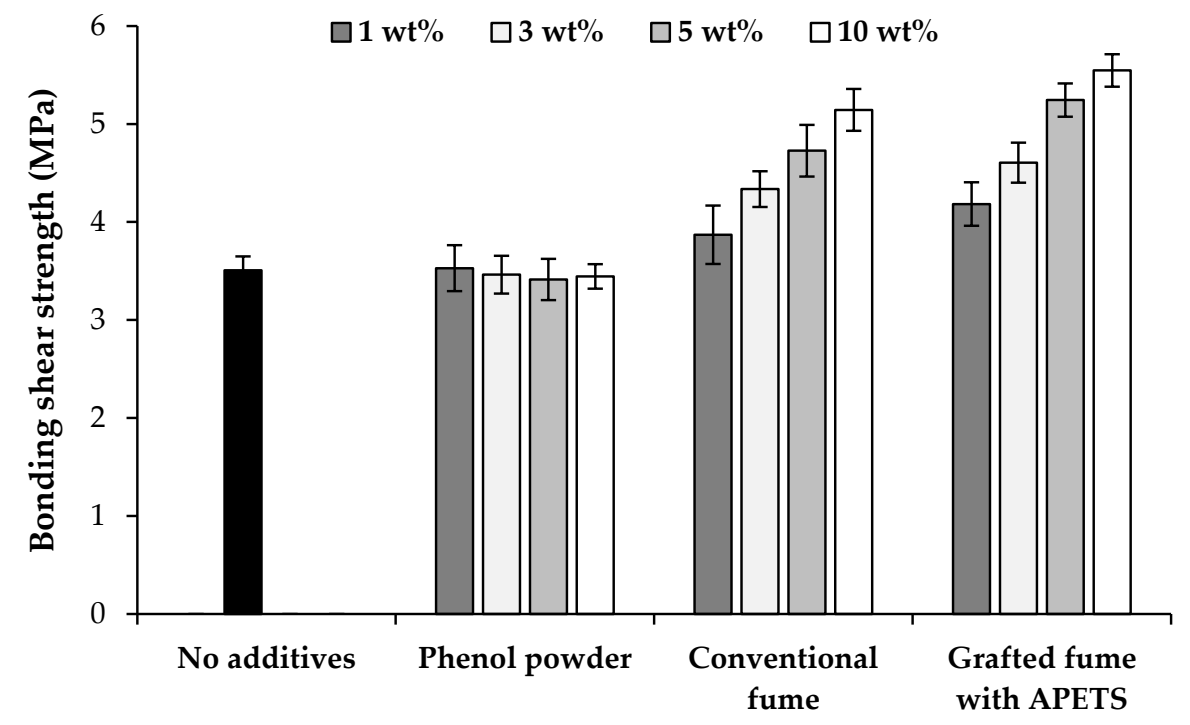

Figure 3. Bonding shear strength of geopolymer binder mixed with various additives using an Automated Bonding Evaluation System (ABES) instrument.

The highest bonding shear strength was observed with the addition of grafted silica fume with APTES. The bonding shear strength of the binder was increased by about $57 \%$ with the addition of $10 \mathrm{wt} \%$ grafted fume. Of course, a part of this shear strength increment was still related to the silica fume itself. The APTES as a grafting agent was also positively influenced by the bonding shear strength of the geopolymer binder. Notably, the APTES also improved the bonding mechanisms of geopolymer with wood. The fractured surface of the wood strips (Figure 4) showed that the common failure mode for geopolymer binder with phenol flakes and conventional silica fume was cohesion failure in the binder, as the binder was observed to stay on top of the two veneer strips. The failure happened in the wood section of the overlapping area in the case of grafted silica fume. This can be related to the improvement of bonding mechanisms between wood and geopolymer binder. The APTES could be converted into silanol and possibly linked to the wood surfaces [32].
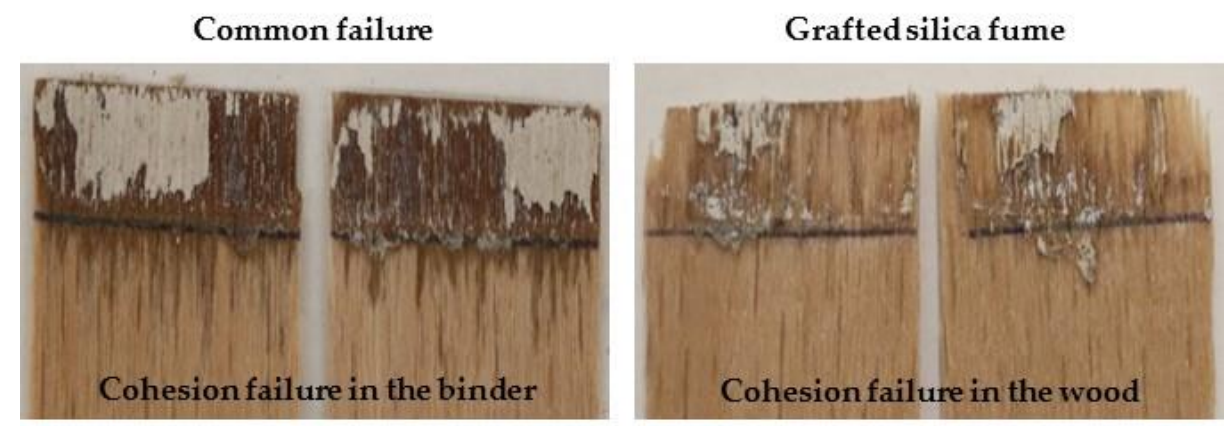

Figure 4. Fractured surface of the geopolymer binder mixed with various additives using the ABES instrument.

\subsection{Binder Characterisation}

Viscosity and gel time of the binders with various types and contents of additives are presented in Table 4 . The viscosity and curing time of the geopolymer binder with no additives were $1040 \mathrm{cP}$ and $83.7 \mathrm{~s}$, respectively. The viscosity was noticeably increased with the addition of phenol flakes into the 
binder recipe, reaching to about 6280 and $10,740 \mathrm{cP}$ after adding $5 \mathrm{wt} \%$ and $10 \mathrm{wt} \%$ phenol based on the metakaolin powder, respectively. Phenol donates a proton to the hydroxyl ions in the alkaline solution, with the phenol becoming the phenolate anion (phenoxide anion). In other words, the phenol will absorb some water in the binder and accordingly increase the binder viscosity [39]. Consequently, the diffusion and mobility of the geopolymer network are reduced. Therefore, the curing reactions of geopolymer may be influenced by diffusion because the mobility of the molecules decreases when the molecular weight increases. The addition of both conventional and functionalized silica fume also increased the geopolymer binder viscosity, but their increasing impact was not as significant as those for the phenol flakes. The final solid content of the geopolymer binders were slightly increased after the admixture of additives into the binder formulation. The higher the binder solid content, the higher the viscosity that was achieved. Furthermore, the differences between the viscosities of the binder with similar content of the additives could be due to their various effects on the geopolymerization process. The lowest viscosity of the binder after addition of the additives belonged to the functionalized silica fume. Viscosity is an essential factor influencing the binder penetration into the porous structure of the wood $[9,11]$.

The effects of additives on the curing time of geopolymer binders are presented in Table 4 . The addition of phenol delayed the gel time of the geopolymer binder to about $90 \mathrm{~s}$. The $\mathrm{pH}$ level of the geopolymer binder strongly influenced the geopolymerization process, as well as the final binder characteristics. A high alkalinity is needed for the appropriate dissolution of the aluminosilicate powder. Phenol is a weak acid that negatively influences the binder curing. Addition of both conventional and functionalized silica fume accelerated the solidification of the geopolymer binder. Silica fume is favored in geopolymer formulation because of its acceptable early-stage strength development [15]. Notably, the gel time in geopolymer binder based on functionalized silica fume was shorter in comparison to those of conventional silica fume. This can be attributed to the alkaline nature of the APTES, leading to faster geopolymerization.

Table 4. Viscosity, gel time, and differential scanning calorimetry (DSC) parameters of the geopolymer binder.

\begin{tabular}{cccccc}
\hline $\begin{array}{c}\text { Additives in } \\
\text { Geopolymer }\end{array}$ & $\begin{array}{c}\text { Amount }(\mathbf{w t} \\
\mathbf{\%})\end{array}$ & $\begin{array}{c}\text { Viscosity } \\
(\mathbf{c P})\end{array}$ & Gel Time (s) & $\begin{array}{c}\text { Onset Temperature } \\
\left({ }^{\circ} \mathbf{C}\right)\end{array}$ & $\begin{array}{c}\text { Peak Temperature } \\
\left({ }^{\circ} \mathbf{C}\right)\end{array}$ \\
\hline No additives & 0 & $1040(48) *$ & $83.7(1.7) *$ & 79 & 98.8 \\
Delta H $(\mathbf{J} / \mathbf{g})$
\end{tabular}

The DSC data are also presented in Table 4 . The onset and peak temperatures of the reference geopolymer binder (no additives) were recorded at $79^{\circ} \mathrm{C}$ and $98.8^{\circ} \mathrm{C}$, respectively, that is, somewhat like that of urea formaldehyde adhesive [5,40]. The onset temperature was not significantly changed with the use of various additives in the geopolymer formulation. The peak temperature of the geopolymer binder was not affected either after the addition of conventional and functionalized silica fume, whereas the addition of phenol flakes slightly reduced the peak temperature to about $95^{\circ} \mathrm{C}$. The curing reactions of the geopolymer binder was generally exothermic and became the main contribution to heat evolution during DSC measurements (Figure 5). The DSC results showed that the heat of reaction obviously decreased with the addition of phenol into the binder formulation. Conversely, the heat of reaction was slightly increased with the addition of both conventional and grafted silica fumes into the geopolymer binder formulation. This indicates that the final heat of reaction of the curing reaction of the geopolymer binders were strongly related to the types of additives. In other words, the heat release 
and reaction temperature depended notably on the raw materials, activators, and reaction conditions. The effect of the silica fume on the final heat of reaction of the curing reaction could be explained by the increase in the reactivity of reactive groups (fast formation of three-dimensional networks) in the curing system. The phenol flakes were negatively influenced by the binder characteristics and created the lowest heat of reaction during curing.

As shown in Figure 5, the endothermic reaction before binder curing was observed for all geopolymer binders with and without additives. This endothermic reaction should not have been related to vapor loss because the analysis was conducted under pressure. This endothermic reaction could be due to the release of water prior to polycondensation of geopolymer components. Furthermore, an endothermic reaction after geopolymerization was also observed only for the geopolymer binder with phenol flakes. The hydrolysis of the phenol or reacted components (e.g., phenoxide anion) might have contributed to this endothermic phenomenon.

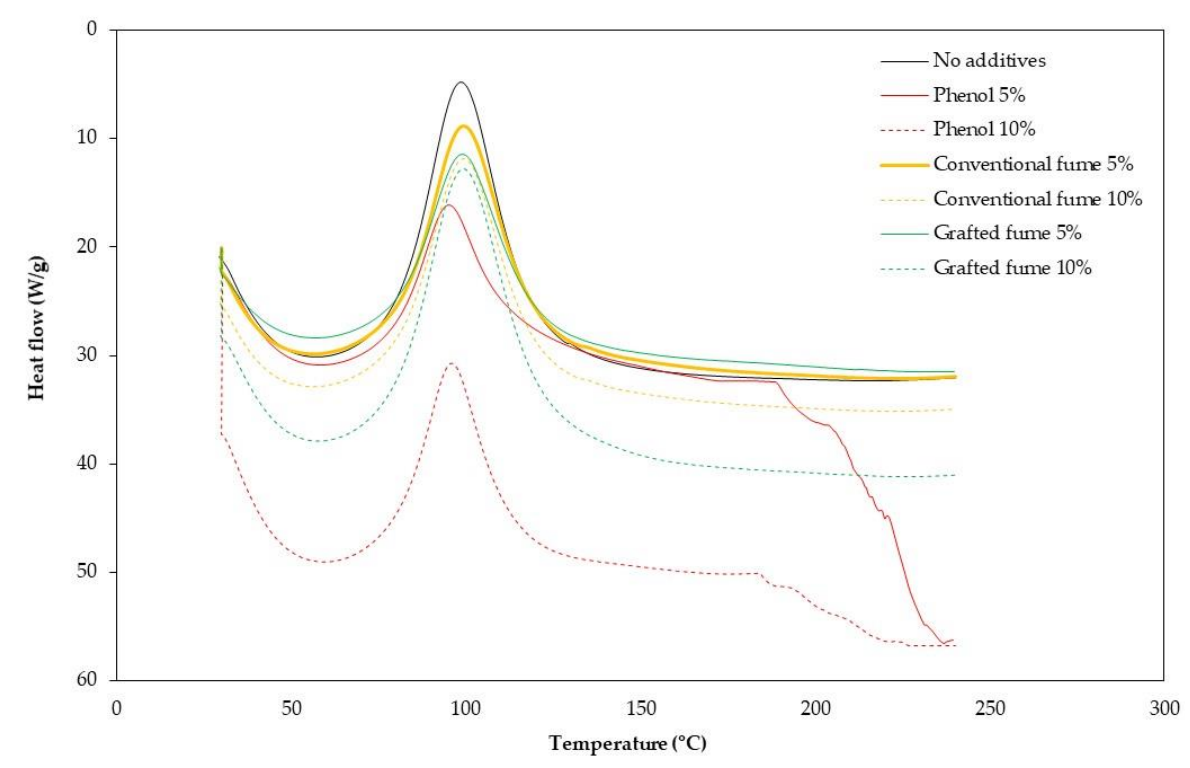

Figure 5. DSC curves of the geopolymer binder mixed with various additives.

\subsection{ATR-FTIR Characterization}

The ATR-FTIR spectra were recorded in the spectral region of $550-4000 \mathrm{~cm}^{-1}$. The ATR-FTIR of the cured geopolymer binder is presented in Figure 6. The peak frequencies were allocated in accordance with previously published peak frequency assignments. The relationship between various groups of $\mathrm{Al}-\mathrm{O}, \mathrm{Si}-\mathrm{O}, \mathrm{Si}-\mathrm{O}-\mathrm{Si}$, and $\mathrm{Si}-\mathrm{O}-\mathrm{Al}$ asymmetric stretch peak positions and the extent of the geopolymerization process is complex, but still helpful for studying the geopolymerization mechanism. The symmetrical stretching of Si-O-Si and Al-O-Si, typical for the metakaolin-based geopolymer, was presented at about $683 \mathrm{~cm}^{-1}$ in all geopolymer binder formulations. This indicates the formation of an alkaline aluminosilicate network [13]. The absorption peak at $970 \mathrm{~cm}^{-1}$ referred to stretching vibrations of Si-O- $\mathrm{R}^{+}$bond $(\mathrm{R}=\mathrm{Na}$ and $\mathrm{K})$. This peak in geopolymer binder with additives shifted to lower wavenumbers (of about $950 \mathrm{~cm}^{-1}$ ). Lower wavenumbers of the Si-O-R $\mathrm{R}^{+}$bonds, also in agreement with the literature data $[9,16]$, presented evidence for a better geopolymerization process.

The peaks at 1217 and $1366 \mathrm{~cm}^{-1}$ referred to an asymmetrical stretching of Si-O-Si and Si-O stretching bands [18]. The higher peak intensity of $1366 \mathrm{~cm}^{-1}$ in the binder with $10 \mathrm{wt} \%$ grafted fume could be related to the more Si-O bands existed in the grafting agent (APTES). The absorption band at about $1640 \mathrm{~cm}^{-1}$ referred to the bending vibration of $\mathrm{O}-\mathrm{H}$ groups [16]. When grafted silica fume was added to the geopolymer binder, a peak at $1737 \mathrm{~cm}^{-1}$ appeared, which can attributed to $\mathrm{C}=\mathrm{O}$ stretching vibration. The vibration bands at about $1200 \mathrm{~cm}^{-1}$ represented that the asymmetric stretching of siloxane groups ( $\mathrm{Si}-\mathrm{O}-\mathrm{Si}$ ) was intensified with the addition of APTES. Furthermore, two 
new peaks at about $2973 \mathrm{~cm}^{-1}$ and $3000 \mathrm{~cm}^{-1}$ were observed, which correspond, respectively, to the symmetric and asymmetric vibration of the $-\mathrm{CH}_{2}$ - and $\mathrm{C}-\mathrm{H}$ groups [32]. The intensities of these peaks were more pronounced at a higher level $(10 \mathrm{wt} \%)$ of functionalized silica fume content, whereas it was not notable in the geopolymer binder with no additives. Absorption bands at $3450 \mathrm{~cm}^{-1}$ represented the stretching vibration of aliphatic amine $(\mathrm{N}-\mathrm{H})$ groups. The broad bands located at about $3300 \mathrm{~cm}^{-1}$, especially at binders having phenol and grafted silica fume, corresponded to the free and bound - $\mathrm{OH}$ and stretching bands of $\mathrm{N}-\mathrm{H}$ group for phenol and 3-aminopropyl-triethoxysilane, respectively [41,42]. Absorption peak at $1231 \mathrm{~cm}^{-1}$ in the geopolymer binder with phenol flakes corresponded to the C-C-O asymmetric stretch. In addition, the peaks at 1480 and $1587 \mathrm{~cm}^{-1}$ related to the $\mathrm{C}=\mathrm{C}$ aromatic ring vibrations of phenoxide anion [39].

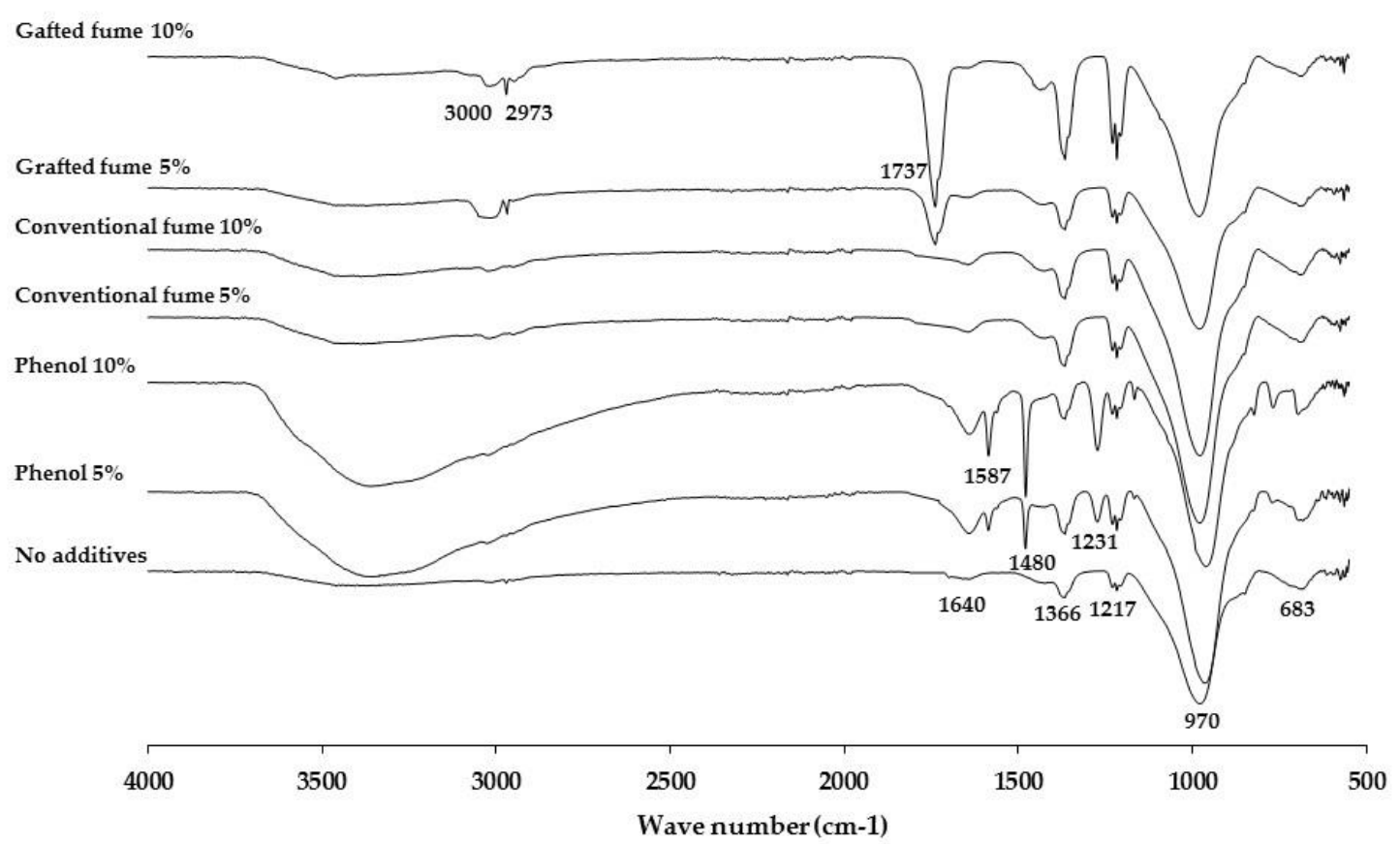

Figure 6. Attenuated total reflection Fourier transform infrared spectroscopy (ATR-FTIR) spectra of table.

\subsection{Shear Strength Analysis}

The shear strengths of LVL samples made of geopolymer binder with and without additives are shown in Figure 7. The shear strength values were significantly higher for the samples with no pretreatment compared to those that received the conditioning treatments of $24 \mathrm{~h}$ water soaking and $6 \mathrm{~h}$ water boiling that are indicators for determining their interior and humid applications, respectively. Referring to Figure 7, the samples experienced a severe change in condition after both water soaking and boiling pretreatments, which likely caused more moisture to penetrate the binder line and decrease the shear strength of the LVL samples. The average loss of shear strength after water soaking and water boiling pretreatments related to the untreated samples were about $50 \%$ and $60 \%$, respectively. The areas exposed to moisture influenced the binder features, deteriorated the quality of geopolymer bonding, and, consequently, destroyed the bonding layers [9,13,28].

Shear strength comparison of the LVL samples made by geopolymer binder with various additives showed that the addition of phenol flakes into the binder formulation significantly reduced the bonding shear strength. This can be explained through the higher viscosity of geopolymer binder, as shown in Table 4, after the addition of phenol. The higher the binder viscosity, the weaker the binder penetration, and accordingly, a weaker mechanical interlock can be feasible between the geopolymer binder and the wood constituents. On the other hand, the bonding shear strength was slightly enhanced with the addition of conventional silica fume. The higher the substitution by silica fume, the higher the bonding 
shear strength in the geopolymer binder. The pores of the geopolymer binder can be refined by the addition of silica fume [15]. Notably, the highest bonding shear strength was obtained by using grafted silica fume with APTES. It was reported that the APTES as grafting agent can improve the interfacial adhesion between organic and inorganic substrates [32]. Hence, it can be concluded that the type of additives added into the binder formulation is an important factor influencing the geopolymerization process and, accordingly, the shear strength of the LVL samples.

Shear strength values for most of the pre-treated samples were lower than $1 \mathrm{MPa}$, which is the upper limit value according to the European standard of EN 314-2. In EN 314-2, a correlation exists between the minimum shear strength and the percentage of wood failure. The higher the wood failure percentage, the lower is the required shear strength. A maximum of approximately $10 \%$ wood failure was observed in both pre-treated samples (cold water soaking and water boiling) produced with geopolymer binder mixed with silica fume that can be attributed to the enhanced bonding mechanism of geopolymer binder with wood. It is supposed that further addition of grafted silica fume in the binder formulation can further improve the bonding quality between wood and geopolymer binder to reach the required level of wood failure according to EN 314-2. The level of wood failure is somewhat dependent on the level and type of bonding mechanisms created between the wood cells and the binder. Wood is a porous material; hence, a mechanical interlock is the most likely bonding mechanism involved between the wood cells and the inorganic binder $[9,11,27]$. Chemical bonding formation between the wood and any mineral components, especially geopolymer binder, has not yet been proven [11]. It is feasible that the APTES used for the grafting of silica fume could have created better bonding mechanisms (e.g., a chemical linkage) with the superficial wood cells that needs to be further explored.

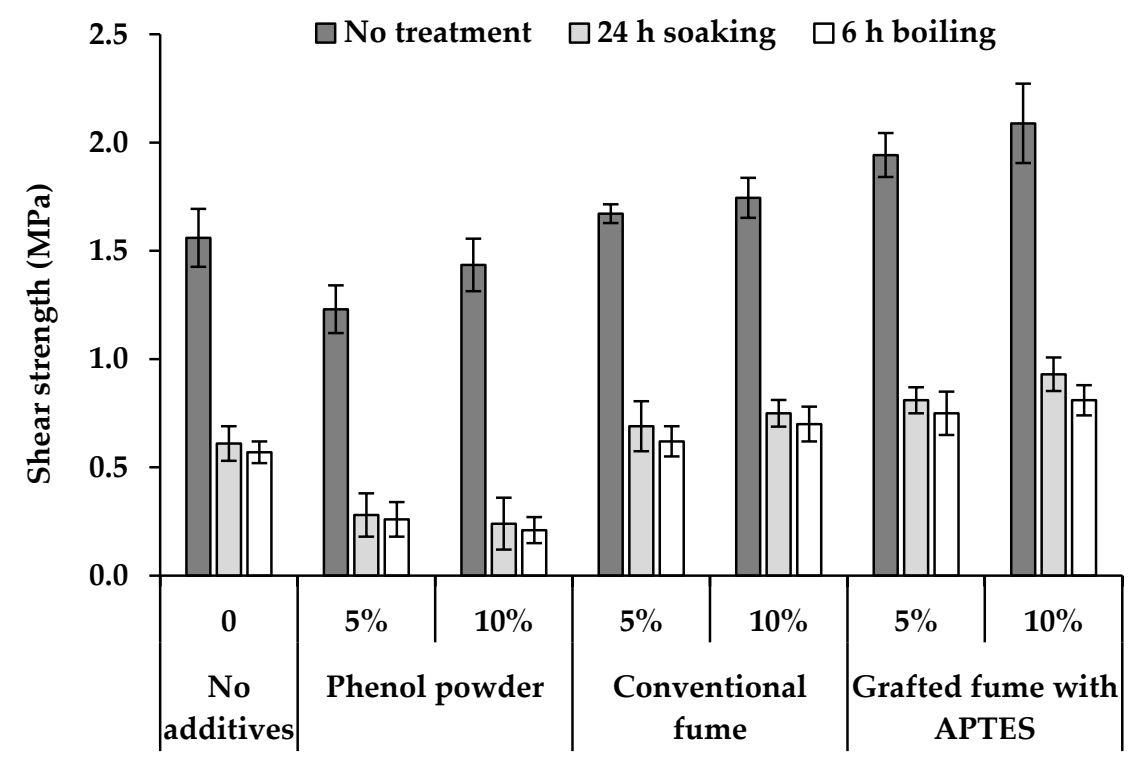

Figure 7. Shear strength of the LVL samples using geopolymer binder mixed with various additives.

\subsection{Bending Properties}

The average values of bending strength (MOR) and modulus of elasticity (MOE) in the bending of LVL samples in both face and edge directions are presented in Figure 8. It is obvious that the type of additives in the geopolymer binder affected the bending properties of the LVL samples. Referring to Figure 8A, LVLs made of geopolymer binder with no additives had a face MOE and MOR of about 13,000 and $93 \mathrm{MPa}$, respectively. The face $\mathrm{MOE}$ was not considerably changed by using various additives in the binder formulation. The face MOR was significantly reduced with the addition of phenol in the binder formulation, whereas the face MOR was increased about $20 \%$ with the addition of the grafted silica fume. In other words, the lowest value of face MOR was observed with a $10 \mathrm{wt} \%$ 
phenol usage (72 MPa), and the highest belonged to the sample with $10 \mathrm{wt} \%$ grafted silica fume (112 MPa). This result is also consistent with the trend observed in bonding shear strength of LVL samples. As was shown above, the shear strength values of LVL samples made of geopolymer binder with phenol were also the smallest due to the higher binder viscosity $[12,30,39]$.
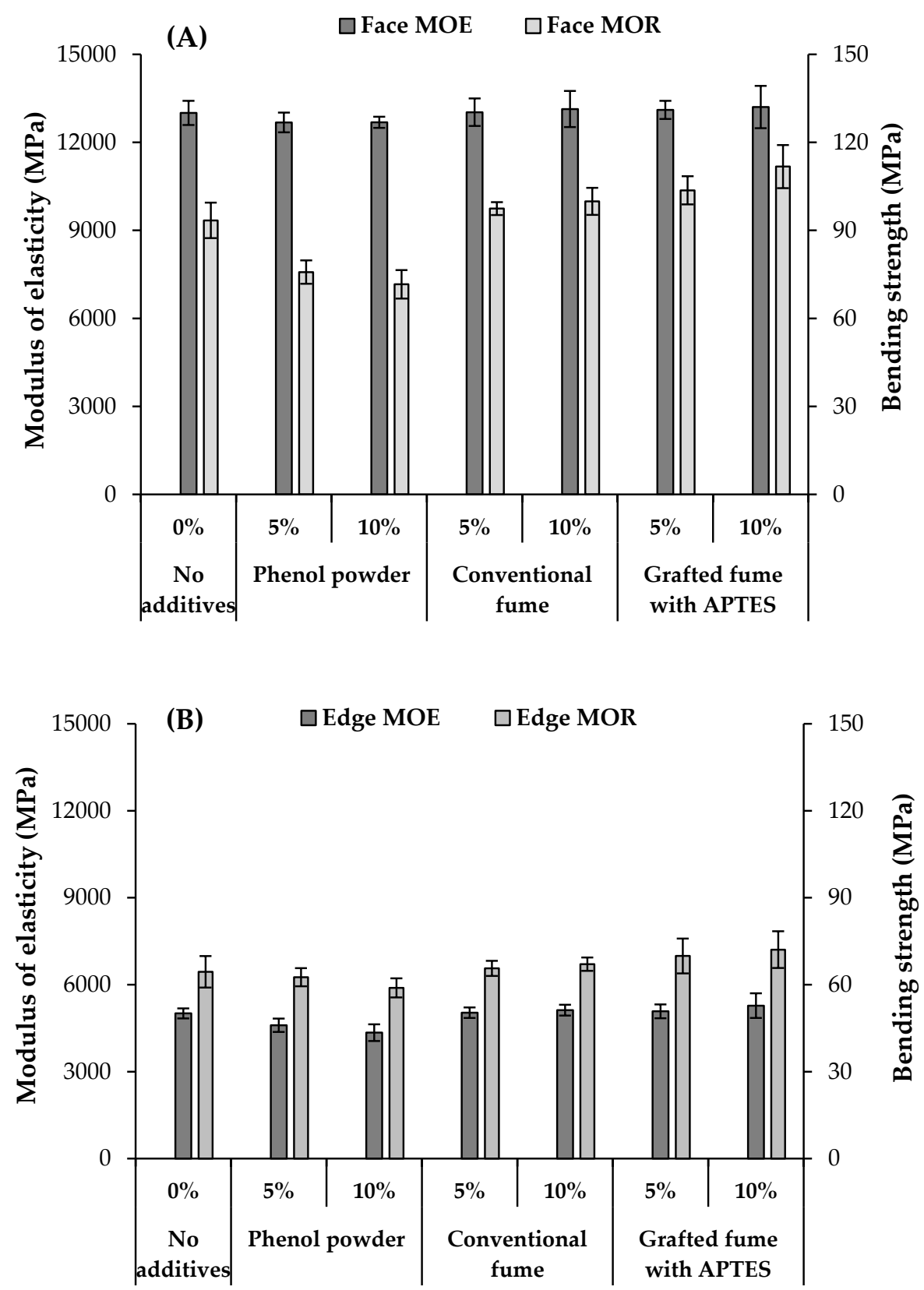

Figure 8. Bending properties in both face (A) and edge (B) direction of the LVL samples using geopolymer binder mixed with various additives. MOE: average values of modulus of elasticity; MOR: average values of bending strength.

Referring to Figure 8B, the additives in the geopolymer binder also showed a significant influence on the edge bending properties. The lowest MOE belonged to the sample with $10 \mathrm{wt} \%$ phenol (4400 MPa), whereas the highest MOE was observed for the sample with $10 \mathrm{wt} \%$ grafted silica fume (5270 MPa). The differences in the values of edge MOE between the reference sample and those made of conventional and grafted silica fume were insignificant. The edge bending strength was increased by about $10 \%$ after adding grafted silica fume to the geopolymer binder formulation. This could be 
due to the improved adhesion mechanisms created between the geopolymer binder and the wood constituents using silica fume $[9,29]$.

The failure modes analysis of the bending samples can also explain the effect of various additives on the bending properties of LVL samples. As stated in Figure 9, the common failure mode of bending samples was a delamination crack that extended longitudinally through the binder line of the LVL samples and significantly influenced the maximum failure load tolerance. This can diminish the bending strength of LVL samples. The bending failure was initiated in the wood layers of LVL samples made of geopolymer binder mixed with grafted silica fume (in both face and edge bending tests). This indicates the improved adhesion between the modified geopolymer binders with the wood constituents.

The mean values obtained for bending strength and MOE of the LVL panels were higher than the limit values for the structural purpose solid wood panels (32 MPa for face MOR and $9000 \mathrm{MPa}$ for face MOE) indicated in the European Standard of EN 13353 [43] for panels having a thicknesses of up to $20 \mathrm{~mm}$.
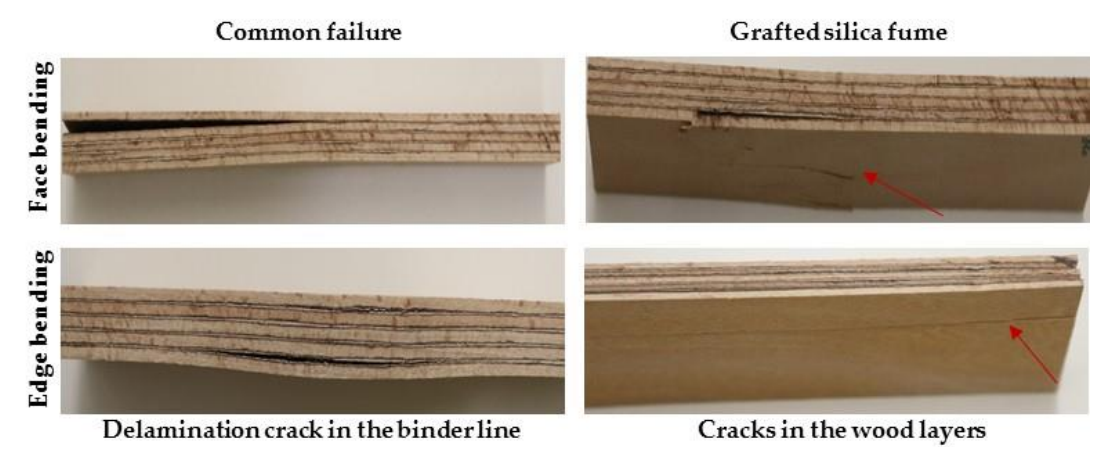

Figure 9. Failure mode in the LVL samples after face and edge bending tests.

\subsection{Compression Strength}

The average values for compression strength of longitudinally loaded LVL specimens (parallel to grain) are presented in Figure 10. The compression strength for the LVL samples made of geopolymer binder with no additives was about $52 \mathrm{MPa}$. A $25 \%$ reduction of compression strength was observed when the phenol was added into the binder. Compression strength was increased to about $60 \mathrm{MPa}$ after adding grafted silica fume to the geopolymer binder. As explained earlier, the grafted silica fume created enhanced bonding mechanisms with wood cells that needs to be further explored.

Failure modes were relatively consistent among groups of test specimens and can be seen in Figure 11. The common failure mode observed in most of the samples was splitting the layers at the geopolymer binder line that indicates a weak bond line quality. Specimens made with grafted silica fume generally started to fail in compression, after which they buckled to one side and compression creases were observed at the specimens' face. This result is also consistent with that trend observed in bending tests of LVL samples, showing an improved adhesion between wood and geopolymer binder with grafted silica fume. 


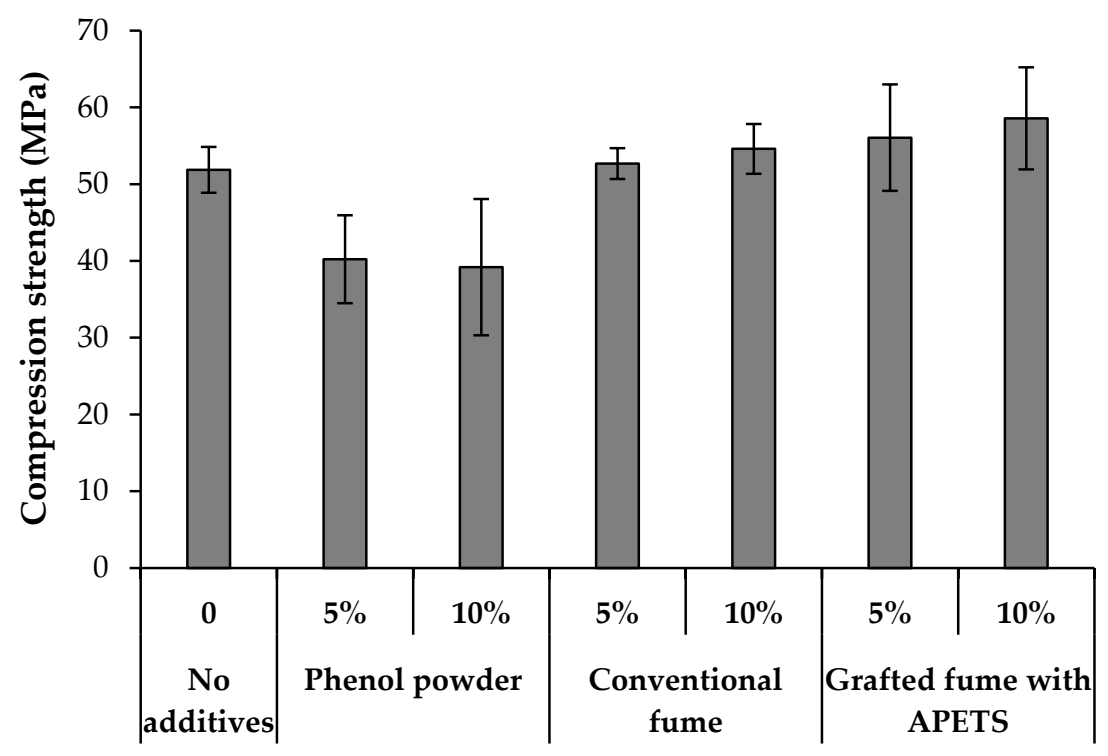

Figure 10. Compression strength values of the LVL samples using geopolymer binder mixed with various additives.
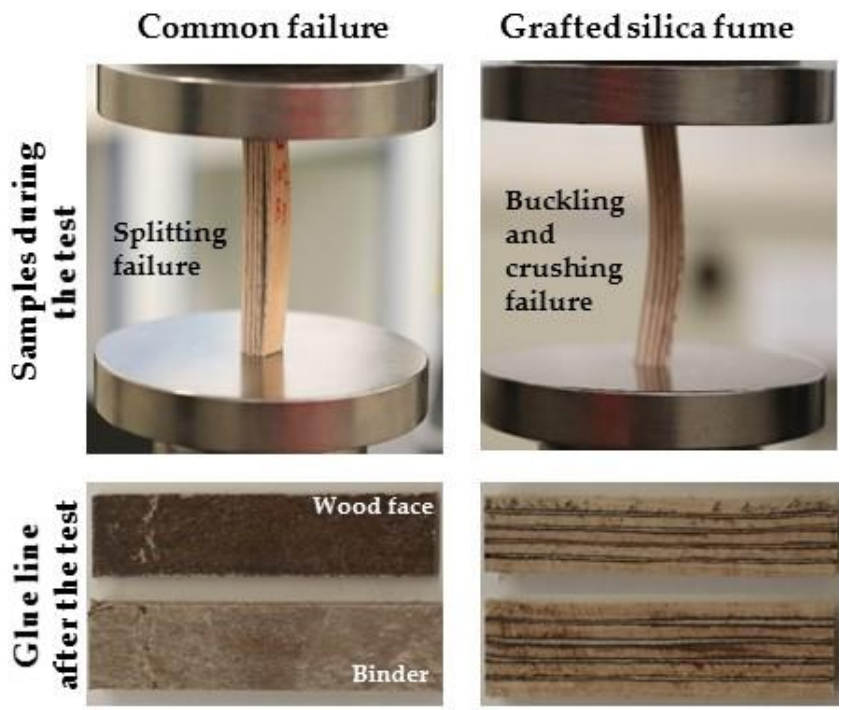

Figure 11. Failure mode in the LVL samples after compression strength test.

\section{Conclusions}

New types of environmentally friendly LVL panels were successfully manufactured using the geopolymer components as binder. The applicability of various additives (phenol flakes, conventional silica fume, and grafted silica fume with APTES) to improve the geopolymer binder features was investigated in this study. The RSM modelling showed that the optimum levels of pressing temperature and time on the geopolymer shear strength were $140{ }^{\circ} \mathrm{C}$ and $112.5 \mathrm{~s}$, respectively. Adding phenol negatively influenced the binder gel time, viscosity, and DSC parameters, whereas the conventional and grafted silica fume showed a positive impact on the geopolymer binder features. The formation of an alkaline aluminosilicate network was confirmed by observing the characteristic peaks of geopolymer at 683 and $970 \mathrm{~cm}^{-1}$. The shifting of the characteristic peak of geopolymer $\left(970 \mathrm{~cm}^{-1}\right)$ towards lower wavenumbers (of about $950 \mathrm{~cm}^{-1}$ ) showed that a better geopolymerization process happened after the admixture different types of additives. The highest mechanical properties (bonding shear strength, bending strength, and compression strength) was obtained by using grafted silica fume with APTES, due to the improvement of interfacial adhesion between wood and geopolymer. 
Mechanical interlocking was the most likely bonding mechanism involved between the wood cells and the geopolymer binder, whereas using APTES as a grafting agent may possibly create a chemical linkage between wood and geopolymer, which must be further explored. It is supposed that further increase of APTES amount can further improve the LVL properties to reach the required level for use in interior and humid application.

Author Contributions: Conceptualization, A.S.; methodology, A.S. and H.T.; investigation, A.S. and H.T.; writing —original draft preparation, A.S.; writing — review and editing, A.S. and H.T.; funding acquisition, H.T. All authors have read and agreed to the published version of the manuscript.

Funding: This research was funded by the Swiss National Science Foundation (SNSF), grant number IZSEZO_186480 (2019). The SNSF is also acknowledged for providing the processing charges of this article.

Acknowledgments: Benjamin Rime (Bern University of Applied Sciences) is acknowledged for his great administrative support given in this project. The authors would also gratefully acknowledge the Wöllner $\mathrm{GmbH}$, Ferropem, and Elkam $\mathrm{GmbH}$ companies for kindly supplying the materials.

Conflicts of Interest: The authors declare no conflict of interest.

\section{References}

1. Ozarska, B. A review of the utilisation of hardwoods for LVL. Wood Sci. Technol. 1999, 33, 341-351. [CrossRef]

2. Eckelman, C.A. Potential uses of laminated veneer lumber in furniture. For. Prod. J. 1993, 43, $19-24$.

3. Ferdosian, F.; Pan, Z.; Gao, G.; Zhao, B. Bio-based adhesives and evaluation for wood composites application. Polymers 2017, 9, 70. [CrossRef] [PubMed]

4. $\quad$ Ayrilmis, N.; Lee, Y.-K.; Kwon, J.H.; Han, T.-H.; Kim, H.-J. Formaldehyde emission and VOCs from LVLs produced with three grades of urea-formaldehyde resin modified with nanocellulose. Build. Environ. 2016, 97, 82-87. [CrossRef]

5. Hassannejad, H.; Shalbafan, A.; Rahmaninia, M. Reduction of formaldehyde emission from medium density fiberboard by chitosan as scavenger. J. Adhes. 2018, 8464, 1-17. [CrossRef]

6. Pizzi, A.; Mittal, K.L. Handbook of Adhesive Technology, 3rd ed.; Taylor \& Francis: Boca Raton, FL, USA, 2018; Volume 66, ISBN 9781498736442.

7. Chen, Z.X.; Lei, Q.; He, R.L.; Zhang, Z.F.; Chowdhury, A.J.K. Review on antibacterial biocomposites of structural laminated veneer lumber. Saudi J. Biol. Sci. 2016, 23, S142-S147. [CrossRef]

8. Ayrilmis, N.; Dundar, T.; Candan, Z.; Akbulut, T. Wettability of fire retardant treated laminated veneer lumber (LVL) manufactured from veneers dried at different temperatures. BioResources 2009, 4, 1536-1544.

9. Bahrami, M.; Shalbafan, A.; Welling, J. Development of plywood using geopolymer as binder: Effect of silica fume on the plywood and binder characteristics. Eur. J. Wood Wood Prod. 2019, 77, 981-994. [CrossRef]

10. Sarmin, S.N.; Welling, J.; Krause, A.; Shalbafan, A. Investigating the possibility of geopolymer to produce inorganic-bonded wood composites for multifunctional construction material-A review. BioResources 2014, 9, 7941-7950.

11. Jin, S.; Li, K.; Li, J.; Chen, H. A low-cost, formaldehyde-free and high flame retardancywood adhesive from inorganic adhesives: Properties and performance. Polymers 2017, 9, 513. [CrossRef]

12. Davidovits, J. Geopolymer Chemistry and Applications, 2nd ed.; Institute Geopolymere: Saint-Quentin, France, 2008; ISBN 9782951482012.

13. Steinerova, M.; Matulova, L.; Vermach, P.; Kotas, J. The brittleness and chemical stability of optimized geopolymer composites. Materials 2017, 10, 396. [CrossRef] [PubMed]

14. Bing-hui, M.; Zhu, H.; Xue-min, C.; Yan, H.; Si-yu, G. Effect of curing temperature on geopolymerization of metakaolin-based geopolymers. Appl. Clay Sci. 2014, 99, 144-148.

15. Khater, H.M. Effect of silica fume on the characterization of the geopolymer materials. Int. J. Adv. Struct. Eng. 2013, 5, 1-10. [CrossRef]

16. Chen, L.; Wang, Z.; Wang, Y.; Feng, J. Preparation and properties of alkali activated metakaolin-based geopolymer. Materials 2016, 9, 767. [CrossRef]

17. Singh, N. Fly ash-based geopolymer binder: A future construction material. Minerals 2018, 8, 299. [CrossRef]

18. Lee, W.K.W.; Van Deventer, J.S.J. Use of infrared spectroscopy to study geopolymerization of heterogeneous amorphous aluminosilicates. Langmuir 2003, 19, 8726-8734. [CrossRef] 
19. Petrič, M. Influence of silicon-containing compounds on adhesives for and andhesion to wood and lignocellulosic materials: A critical review. Rev. Adhes. Adhes. 2018, 6, 26-81. [CrossRef]

20. Ye, H.; Zhang, Y.; Yu, Z.; Mu, J. Effects of cellulose, hemicellulose, and lignin on the morphology and mechanical properties of metakaolin-based geopolymer. Constr. Build. Mater. 2018, 173, 10-16. [CrossRef]

21. Prud'homme, E.; Michaud, P.; Peyratout, C.; Smith, A.; Rossignol, S.; Joussein, E.; Sauvat, N. Geomaterial foam to reinforce wood. Strateg. Mater. Comput. Des. Ceram. Eng. Sci. Proc. 2010, 31, 3-10.

22. Gouny, F.; Fouchal, F.; Maillard, P.; Rossignol, S. Study of the effect of siliceous species in the formation of a geopolymer binder: Understanding the reaction mechanisms among the binder, wood, and earth brick. Ind. Eng. Chem. Res. 2014, 53, 3559-3569. [CrossRef]

23. Berzins, A.; Morozovs, A.; Gross, U.; Iejavs, J. Mechanical properties of wood-geopolymer composite. Eng. Rural Dev. 2017, 16, 1167-1173.

24. Chen, T.; Niu, M.; Xie, Y.; Wu, Z.; Liu, X.; Cai, L.; Zhuang, B. Modification of ultra-low density fiberboards by an inorganic film formed by Si-Al deposition and their mechanical properties. BioResources 2015, 10, 538-547. [CrossRef]

25. Chen, T.; Wu, Z.; Niu, M.; Xie, Y.; Wang, X. Effect of Si-Al molar ratio on microstructure and mechanical properties of ultra-low density fiberboard. Eur. J. Wood Wood Prod. 2016, 74, 151-160. [CrossRef]

26. Shalbafan, A.; Welling, J.; Hasch, J. Geopolymers as potential new binder class for the wood based composite industry. Holzforschung 2016, 70, 755-761. [CrossRef]

27. Bekhta, P.; Sedliačik, J. Environmentally-friendly high-density polyethylene-bonded plywood panels. Polymers 2019, 11, 1166. [CrossRef]

28. Berzins, A.; Morozovs, A.; Van Den Bulcke, J.; Acker, J. Van Softwood surface compatibility with inorganic geopolymer. Adv. Mater. Proc. 2017, 2, 793-798. [CrossRef]

29. Shalbafan, A.; Welling, J.; Hasch, J. Effect of aluminosilicate powders on the applicability of innovative geopolymer binders for wood-based composites. Eur. J. Wood Wood Prod. 2017, 75, 893-902. [CrossRef]

30. Tavor, D.; Wolfson, A.; Shamaev, A.; Shvarzman, A. Recycling of industrial wastewater by its immobilization in geopolymer cement. Ind. Eng. Chem. Res. 2007, 46, 6801-6805. [CrossRef]

31. Prud'homme, E.; Michaud, P.; Joussein, E.; Peyratout, C.; Smith, A.; Arrii-Clacens, S.; Clacens, J.M.; Rossignol, S. Silica fume as porogent agent in geo-materials at low temperature. J. Eur. Ceram. Soc. 2010, 30, 1641-1648. [CrossRef]

32. Song, W.; Wei, W.; Wang, D.; Zhang, S. Preparation and properties of new plywood composites made from surface modified veneers and polyvinyl chloride films. BioResources 2017, 12, 8320-8339.

33. European Committee for Standardisation. Laminated Veneer Lumber (LVL)_Defenitions, Classification and Specifications (Includes Amendment A1:2009); European Norm EN 14279:2009; European Committee for Standardization: Brussels, Belgium, 2009.

34. European Committee for Standardisation. Wood-Based Panels-Determination of Modulus of Elasticicty in Bending and of Bending Strength; European Norm EN 310:1993; European Committee for Standardization: Brussels, Belgium, 1993.

35. European Committee for Standardisation. Plywood—Bonding Qulaity_Part 1: Test Methods; European Norm EN 314-1:2005; European Committee for Standardization: Brussels, Belgium, 2005.

36. European Committee for Standardisation. Plywood-Bonding Quality_Part 2: Requirements; European Norm EN 314-2:1993; European Committee for Standardization: Brussels, Belgium, 1993.

37. European Committee for Standardisation. Timber Structures-Structural Timber and Glued Laminated Timber-Determination of Some Physical and Mechanical Properties; European Norm EN 408:1995; European Committee for Standardization: Brussels, Belgium, 1995.

38. Asadi, M.; Nemati, A.; Naghizadeh, R.; Arzani, K.; Fahim, J. Effect of temperature and activator molar of $\mathrm{Na}_{2} \mathrm{O}$ to $\mathrm{SiO}_{2}$ in the process of synthesis and microstructure of cement geopolymer. J. Adv. Mater. Process. 2013, 1, 3-10.

39. Kotorlenko, L.A.; Aleksandrova, V.S. Spectral manifestations of change in electronic structure in phenol-phenolate anion-phenoxy radical series. Theor. Exp. Chem. 1982, 18, 97-99. [CrossRef]

40. Xing, C.; Deng, J.; Zhang, S.Y.; Riedl, B.; Cloutier, A. Differential scanning calorimetry characterization of urea-formaldehyde resin curing behavior as affected by less desirable wood material and catalyst content. J. Appl. Polym. Sci. 2005, 98, 2027-2032. [CrossRef] 
41. Pizarro, J.; Castillo, X.; Jara, S.; Ortiz, C.; Navarro, P.; Cid, H.; Rioseco, H.; Barros, D.; Belzile, N. Adsorption of $\mathrm{Cu} 2+$ on coal fly ash modified with functionalized mesoporous silica. Fuel 2015, 156, 96-102. [CrossRef]

42. Erdem, A.; Shahwan, T.; Çaĝir, A.; Eroĝlu, A.E. Synthesis of aminopropyl triethoxysilane-functionalized silica and its application in speciation studies of vanadium (IV) and vanadium (V). Chem. Eng. J. 2011, 174, 76-85. [CrossRef]

43. European Committee for Standardisation. Solid Wood Panels (SWP)_Requirements; European Norm EN 13353: 2003; European Committee for Standardization: Brussels, Belgium, 2003.

(C) 2020 by the authors. Licensee MDPI, Basel, Switzerland. This article is an open access article distributed under the terms and conditions of the Creative Commons Attribution (CC BY) license (http://creativecommons.org/licenses/by/4.0/). 